This is a post-print (author's final draft) of an article in "Semiotica" (2001), 134, 1/4, pp. 599-633. Walter de Gruyter. [Original page numbers between square brackets]. Details of the definitive version are available at http://www.reference-global.com/toc/semi/2001/134

\title{
Biological roots of musical epistemology: Functional cycles, Umwelt, and enactive listening
}

\section{MARK REYBROUCK}

\section{Introduction}

[599] This article is about musical epistemology. Rather than stating that music, as an artefact, is 'out there', ready to be discovered, I claim that music knowledge must be generated, as a product of development, and that music cognition is not a path towards a true understanding of the music as an ontological category, but a tool for adaptation to the sonic world. The concept of adaptation is a biological concept, but it is possible to transpose it to the realm of cognition, as did Piaget:

My central aim has always been the search for the mechanisms of biological adaptation and the analysis and epistemological interpretation of that higher form of adaptation which manifests itself as scientific thought. (Piaget 1977: xi)

An organism that is 'adapted' has found a way of coping with the world in which it lives. Knowledge as an instrument of adaptation is not concerned with the representation of a 'real world' but is a tool in the pursuit of equilibrium and to steer clear of external perturbations and internal contradictions. This purely biological way of thinking led Piaget to a theory of knowledge that formulates the conceptual structure of knowledge as the product of active knowers who shape their thinking to fit the constraints they experience. This is, in fact, the constructivist orientation of knowledge, as advocated by Glasersfeld (1995a, 1995b) in what is commonly known as 'radical constructivism':

What is radical constructivism? It is an unconventional approach to the problems of knowledge and knowing. It starts from the assumption that knowledge, no matter how it be defined, is in the heads of the persons, and that the thinking subject has no alternative but to construct what he or she knows on the basis of his or her own experience. What we make of experience constitutes the only world we consciously live in. It can be sorted into many kinds, such as things, self, others, and so on. But all kinds of experience are essentially subjective, and [600] though I may find reasons to believe that my experience may not be unlike yours, I have no way of knowing that it 
is the same. (1995b: 1)

What we call knowledge is the result of our own construction and of how we shape the world we experience. This claim is contrary to the realist dogma that there is an objective world 'out there'. It relinquishes the conception of knowledge as a representation of an independent reality, in favor of an organism-dependent way of knowing that is relative to its way of experiencing. Knowledge, here, is not a picture of reality, but a repertoire of actions and thoughts which in past experience have turned out to be successful (Glasersfeld 1996).

I will take these claims as a starting point for developing some ideas about music cognition and dealing with music (for an introduction, see McAdams and Bigand 1993; McAdams and Deliège 1989; Tighe and Dowling 1993; Jones and Holleran 1992; Dowling and Harwood 1986; Serafine 1988; Sloboda 1985). Music, in fact, has a special status as there is no linear and causal relationship between the musical stimuli (the work as an artefact) and the experience of the listener (Handel 1989). The central question of music cognition therefore has to be stated in terms of what we hear when we listen to music (DeBellis 1995; Delalande 1998, 1987, 1984; Brunner 1998; Trehub and Trainor 1993). Dealing with music, in fact, is rather complex and leans upon listening strategies that are highly idiosyncratic. What is essential in becoming an expert listener is the ability to make sense out of the sonorous universe, somewhat analogous to the way an animal or human being makes sense out of his environment (see the whole field of musical semiotics: Tarasti 1995, 1987; Miereanu and Hascher 1998; Stefani, Marconi, and Tarasti 1998). Music, however, deals with manmade environments, that are cultural constructions. Sound, on the other hand, is everywhere in nature, and nature offers beautiful examples of soundscapes that can be categorized as sonic biotopes or habitats. What I am suggesting here is an ethological and ecological approach to the sonic environment. A somewhat related strand of thought was already advocated by Russolo in his 'L'art des bruits' (1975), in which he studied a multitude of noise sounds (see also the entry 'les bruits du monde' in Molino 1988). The approach is challenging in providing new conceptual tools for dealing with music and in bringing together biology, humanities, and music. A starting point is the whole area of biosemiotics and the related question of the semiotization of nature.

One of the earliest manifestations of this trend can be found in the work of the Estonian scholar Jakob von Uexküll, who developed an unprecedented, innovative theory of signs, the scope of which was [601] nothing less than the semiosis in life processes in their entirety. It created and established the basis for a comprehensive new domain that is now called biosemiotics (Sebeok 1998; Hoffmeyer 1996, 1997). His influential theory that 
is known as 'Umwelt-research' focuses on the phenomenal world of organisms, i.e., the world around animals as they themselves perceive it, and this is, in fact, an ethological approach. Or, as Konrad Lorenz it has pointed out 'the research programme mapped out [by von Uexküll] is pretty nearly identical with that of ethology' (Lorenz 1971: 275).

But also the ecological approach is a promising area of research (see, e.g., Martindale and Moore 1989; McAdams 1993; Neisser 1987; Godøy 1999). According to Ernst Haeckel, who first coined the term, ecology is 'the science of the relations between the organisms and the environmental outer world' (Haeckel 1988 [1866]: 286). The related term of ecosemiotics can be defined as the study of the semiotic interrelations between organisms and their environment (for a critical definition, see Kull 1998c). This definition, according to Nöth(1998), presupposes that the center of interest of an ecological semiotics is not a homo semioticus, but an organismus semioticus. And still more fundamental is the question concerning the relationship between the organism and its environment. Human beings are organisms that are enmeshed within webs of environmental relations that are mediated by culture (Ingold 1992). Humans therefore not only perceive nature but also cultural artefacts. The nature-culture dualism, however, can be substituted by an understanding that proceeds from a notion of the mutualism of person and environment (Ingold 1992). To achieve this, an alternative theory of perception is required that shows how it is possible for persons to acquire direct knowledge of their environments in the course of their practical activities. This is the central claim of Gibson's $(1979,1982)$ ecological theory of perception. Perception, however, is not always without conscious processing. Schooled perception leans heavily on cognitive mediation as well.

\section{Mediation and cognitive penetration: The sign as cognitive tool}

Teachers in music education are well aware of the difficulties of describing music experience in an objective way. Modern technology offers possibilities of description, production, and manipulation of the sound, but this does not guarantee a better understanding of the music. Listening, in fact, is highly idiosyncratic and is so complex that multiple hearings are possible (Bamberger 1991; Delalande 1987). Listening, [602] furthermore, involves a kind of listening strategy, that is the outcome both of genetic predispositions and of learning processes (Aiello and Sloboda 1994; Deliège and Sloboda 1996; Papoušek 1996; Hargreaves 1996, 1986; Imberty 1996). Central in this process is the shaping of the human-environment interaction, since the human being is not programmed to react upon the stimuli 
in a simple stimulus-response process, but in a way that is mediated by a mediating instance (Reybrouck 1999b). This mediation between stimulus and response can be offered by an external mediator, but internal mediation is possible as well. The role of cognitive penetration (Pylyshyn 1985) has to be considered here and the pioneering work of Vygotsky (1978) can be a starting point. Leaning upon Engels' concept of human labor and tool use as the means by which man changes nature and transforms himself (Engels 1940), he extended this concept of mediation in human-environment interaction to the use of signs as well as tools:

The inventions and use of signs as auxiliary means for solving a given psychological problem (to remember, compare something, report, choose, and so on) is analogous to the invention and use of tools in one psychological respect. The sign acts as an instrument of psychological activity in a manner analogous to the role of a tool in labor. (Vygotsky 1978: 52)

The sign operation, then, requires an intermediate link between stimulus and response, as a kind of second order stimulus that is drawn into the operation it fulfills. The result is a new relation between $\mathrm{S}$ and $\mathrm{R}$, with the subject being 'actively engaged in establishing such a link' (Vygotsky 1978: 39). In this new process the direct impulse to react is inhibited, and an auxiliary stimulus that facilitates the completion of the operation by indirect means is incorporated. This auxiliary stimulus transfers the psychological operation to higher and qualitatively new forms of behavior that break away from biological development and create new forms of a culturally-based psychological process. Or, as Vygotsky put it: 'All the higher psychic functions are mediated processes and signs are the basic means used to master and direct them' (Vygotsky 1962: $56)$.

I am inclined to stress the importance of cognitive penetration and mediation. There is, however, a whole domain of stimuli that are processed in a quasiautomatic manner, without or with minimal conscious processing. Some perception codes are wired-in, and are functioning at very low levels of the sensory hierarchy. With ascending level of abstraction, the role of cognitive processing grows gradually. Rather than thinking in terms of a dichotomy, however, I prefer to think in terms of a continuum between lower and higher levels of processing, stressing the role of direct perception and of cognitive mediation, that [603] is the outcome of learning processes. This is the old debate between nature-nurture and the distinction between nativism and empiricism (Reybrouck 1997, 1989; Hargreaves 1986). There is, however, growing evidence that enactive cognition is both dependent upon sensory experience that proceeds in a quasi-automatic way and higher-level cognitive processing that proceeds at higher levels of abstraction. 
In order to develop listening strategies it is necessary to start from lower levels and to proceed to higher levels of processing. The analogy with the ways in which animals make sense of their environment can be very useful here. I therefore take the conceptions of ecosemiotics as operational tools for describing the process of how an organism (the listener) is dealing with his environment (the music).

\section{Organism and environment: The concept of Umwelt}

An environment is all that surrounds. It therefore presupposes some- thing to be surrounded. This means that there is no organism without an environment and no environment without an organism (Lewontin 1982: 160). There is, however, the environment as a vast container filled with objects, and from this analogy comes the ecological concept of niche - a little corner of the world an organism occupies - and to which it has fitted itself through a process of adaptation. To quote Ingold:

If a vase be removed from an alcove, a niche remains for a small object that might appropriately fill the vacant space; by analogy it is implied that the ecological niche of an organism is independently specified by the essential properties of the environment, which impose the conditions of functioning to which any occupant must conform. Thus, the very notion of adaptation entails that niches exist in the environment prior to the organisms that fill them. The environment sets the problem, in the form of a challenge; the organism embodies the solution, in the form of its adaptive response. However, this analogy ignores the most fundamental property of all animals: unlike vases, they both perceive and act in their environments. Indeed, perception and action are not really separable at all. (Ingold 1992: 40-41)

Environments of animals and men mostly do not fit the concept of niche. They are 'subjective and meaningful universes' that are constituted within their specific life activities and are to be clearly distinguished from the environment or the surroundings of the animal as these appear to the indifferent observer. It was Jakob von Uexküll who introduced the concept of 'Umwelt' (1973 [1928], 1982 [1940], 1957 [1934]) for describing this subjective universe. In A Stroll Through the Worlds of [604] Animals and Men, first published in 1934, he describes his research project:

The best time to set out on such an adventure is on a sunny day. The place, a flowerstrewn meadow, humming with insects, fluttering with butterflies. Here we may glimpse the worlds of the lowly dwellers of the meadow. To do so, we must first blow, in fancy, a soap bubble around each creature to represent its own world, filled with the perceptions which it alone knows. When we ourselves then step into one of the 
bubbles, the familiar meadow is transformed. Many of its colorful features disappear, others no longer belong together but appear in new relationships. A new world comes into being. Through the bubble we see the world of the burrowing worm, of the butterfly, or of the field mouse; the world as it appears to the animals themselves, not as it appears to us. This we may call the phenomenal world or the self-world of the animal. (von Uexküll 1957 [1934]: 5)

And further:

We no longer regard animals as mere machines, but as subjects whose essential activity consists of perceiving and acting. We thus unlock the gates that lead to other realms, for all that a subject perceives becomes his perceptual world and all that he does, his effector world. Perceptual and effector world together form a closed unit, the Umwelt. These diÄerent worlds, which areas manifold as the animals themselves, present to all nature lovers new lands of such wealth and beauty that a walk through them is well worth while, even though they unfold not to the physical but only to the spiritual way. (1957 [1934]: 6)

Listening to music is highly related to Umwelt-research. Music is not to be considered as an acoustic niche, but as a subjective environment, and the concept of Umwelt, according to Kull (1998b), is the semiotic world of organisms. The Umwelt is a collection of subjective meanings imprinted upon all objects of a subjective subset of the overall world. It includes all the meaningful aspects of the world for a particular organism. The same holds true for the conception of musical Umwelt. Each listener has his listening competence that is the result of previous interactions with the sound, and the way he constructs his musical Umwelt is dependent upon the way he gives meaning to the sounds. This is in close parallel with the statement of von Uexküll that the objective qualities of objects are not attributes of the objects themselves, but are acquired by the objects' having entered into diverse relationships with subject organisms. It is the organism that fits the world to itself, by ascribing functions to the objects it encounters and thereby integrating them into a coherent system of its own (Ingold 1992). His environment, then, is the projection or 'mapping out' of its internal organization onto the outside world, or 'nature organized by an organism' (Lewontin 1982: 160).

[605] This line of thought is closely related to the ecological approach of Gibson $(1982,1979,1966)$, who claims that animals perceive environmental objects in terms of what they afford for the consummation of behavior: 'The affordances of an environment are what it offers the animal, what it provides or furnishes, either for good or ill' (1979: 127). What matters here are not the objective qualities of objects, but their qualities that render them apt for specific activities. von Uexküll argued in similar lines when he spoke of the particular qualities or 'functional tones' of objects. He gives the example of a tree that has different 
qualities with respect to the respective Umwelten of the animal and human beings that confer these qualities on it (shelter for the fox, support for the owl, thoroughfare for the squirrel, hunting grounds for the ant, egg-laying facilities for the beetle, source of valuable raw material for the forester) (Von Uexküll 1957 [1934]: 73-79).

Observation teaches that each animal moves within its habitat and confronts a number of objects, with which it has a narrower or wider relationship. The objects mostly are not neutral objects, since they are transformed into meaningcarriers as soon as they enter into a relationship with a subject. To demonstrate the proof of this assertion von Uexküll gives the example of an angry dog that is barking at somebody on a country road. In order to drive it off, the person picks up a stone and throws it at the dog. It is the same object (the stone) which first lies on the ground and that then was thrown at the dog. No physical or chemical properties of the stone have altered and yet, a fundamental transformation has taken place: it has changed its meaning. As long as the stone was incorporated in the country road, it served as a support for the walker's feet and its meaning lay in its playing a part in the performance of the path. Hence, we may say that it had acquired a 'path-quality'. This changed fundamentally when the stone was picked up to be thrown at the dog. The stone became a missile and a new meaning became imprinted on it: it had acquired a 'throw-quality' (von Uexküll 1982 [1940]: 27).

The example shows the importance and primacy of functional relations. It is a major claim of Gibson's ecological psychology and has been stressed by the Belgian experimental psychologist Albert Michotte who stated that objects are experienced ultimately in terms of their functional significance for our activities:

\footnotetext{
It is futile to study perception 'in itself '. It must be treated as a 'phase of action' in relation to the motor and intellectual activity of the individual_ An object only aects behavior in so far as it has meaning, and this only arises from its functional relations to the other objects, be they spatial or temporal relations, or relations of causality or purposiveness, etc. (Costall 1991: 54)
}

[606] The same strand of thought can be found in modern research on categorization that stresses the importance of functionality and goal-directed activities (Mazet 1991). What is proposed here is the duality of perceptual pregnancy and functional signification as organizational principles of categorization. The functional properties, then, can be expressed on the basis of the linguistic expression 'for+verb' (e.g., a chair is 'for sitting down') (Dubois 1986) and on the basis of what language theorists call their 'activity signature'. They have studied, for example, the muscular habits associated with the word 'chair' (what the body normally goes through to sit down on it, and to get up) and found that these motor habits help to define the concept of 'chair', to 
distinguish it from other objects that can be sat on. What is meant here are concept structures that must have some identity of their own, within our procedural or moto-memories (Beck 1987). The same idea, however, was already advocated by von Uexküll:

The work of the organism (as meaning-utilizer) always corresponds to the complementary function of the object (as meaning-carrier). Thus, for example, a chair is only defined by its complementary function to the operation of our body, namely sitting. It has a `sitting quality'. (1935: 367)

Applying these insights to music is likely to become a challenging area of research (Reybrouck 2001; Lidov 1987; Delalande 1984; Molino 1988; Godøy $1999,1997 \mathrm{~b}$ ) since it allows categorizations of sound in terms of action verbs rather than in terms of substantives. The images of singular sound-producing actions such as hitting, stroking, kicking, blowing, as well as more complex or compound actions such as drumming a rhythmic pattern, sliding up and down a melodic contour, or the formantic changes in timbre that result from the changing of the shape of the vocal tract can serve as an example here (Godøy 1999: 90). But the six classes of noises as presented by Russolo (1975: 40) can do as well: (1) buzzing, crack/bang, noise of falling water, noise of diving, roaring, (2) whistling/ hissing, snoring, sniÅng, (3) murmuring, muttering, rustling, grumbling, grunting, glug-glug, (4) shrill noise, creaking, humming, crackling/ sputtering, trampling, (5) percussion noise on metal, wood, skin, stone, terra-cotta, (6) voices of men and animals, screams, sighing, crying, laughter, rattling and sobbing. What really matters, then, are not the acoustic properties but affordances and viabilities.

\section{Experiential cognition and dealing with music}

Dealing with music cannot be reduced to a structural description of the sound. Such an approach is lacking in not describing the individual music [607] user. To quote Laske: 'Goal state analysis [score analysis] of music misses the crucial point that music is above all a human experience, not merely a set of artefacts or "structures" (1977: 71; see also Polednak 1985). Dealing with music is a kind of experiential cognition that leans upon sensorimotor processing and principles of cognitive economy. Cognitive claims, however, are in danger of being nominalistic, andexperiential claims are mostly empiricist claims. The question, then, is how to bring together these diverging paradigms (nominalism and realism). I therefore introduce some paradigms that are all in a way related to the basic concepts of von Uexküll's theory of meaning, and that offer a partial answer to the sketched dichotomy.

A good starting point is William James' statement that 
It is possible ... to join the rationalists in allowing conceptual knowledge to be self-sufficing, while at the same time one joins the empiricists in maintaining that the full value of such knowledge is got only by combining it with perceptual reality again. (James 1968: 327)

This is in a nutshell his doctrine of radical empiricism that states that the significance of concepts consists always in their relation to perceptual particulars. To quote more extensively:

Having now set forth the merits of the conceptual translation, I must proceed to show its shortcomings. We extend our view when we insert our percepts into our conceptual map. We learn about them, and of some of them we transfigure the value; but the map remains superficial through the abstractness, and false through the discreteness of its elements; and the whole operation, so far from making things appear more rational, becomes the source of quite gratuitous unintelligibilities. Conceptual knowledge is forever inadequate to the fullness of the reality to be known. Reality consists of existential particulars as well as of essences and universals and class-names, and of existential particulars we become aware only in the perceptual flux. The flux can never be superseded. (James 1976: 245)

A second approach is the experientialist approach of cognitive semantics (Lakoff 1987, 1988; Johnson 1987) that attempts to characterize meaning in terms of the nature and experience of the organisms doing the thinking. Experiential realism characterizes meaning in terms of embodiment, that is, in terms of our collective biological capacities and our physical and social experiences as beings functioning in our environment (Lakoff 1987: 266-267). The basic epistemological finding of this 'experientialist' (cognitive semantics) approach is that knowledge must be understood in terms of structures of embodied human understanding, as an interaction of a human organism with its environment (Johnson 1987: 209).

[608] A closely related approach is Jackendoff's conceptual or mentalistic semantics. In stating the priority of Conceptual Semantics over Real Semantics, he argues that

one cannot take for granted the 'real world' as the domain of entities to which language refers. Rather, the information that speakers can convey must be about their construal of the external world, where one's construal is the result of an interaction between external input and the means available to internally represent it. (Jackendoff 1987: 83)

The characteristics of these entities seem to be regarded in terms of 'how humans structure the world — what is real for us' (1987: 151-152).

The following approach is called non-objectivist semantics (Johnson 1987). 
Meaning, according to this view, is always a matter of human understanding, which constitutes our experience of a common world that we can make some sense of. Such understanding involves image schemata and their metaphorical projections, as well as propositions and is highly dependent upon structures of embodied imagination, which are a chief means by which we 'have a world' that we can partially comprehend and reason about. The relevant notion of understanding, as a way of 'being in' or 'having' a world, highlights the dynamic, interactive character of understanding (and meaning). Meaning is not merely a fixed relation between sentences and objective reality, as objectivism would have it. Understanding, on the contrary, is an event in which one has a world, or, more properly, a series of ongoing related meaning events in which one's world stands forth, as has been recognized already in the work of Heidegger and Gadamer. The non-objectivist claim therefore opposes the viewpoint that transcends human embodiment, cultural embeddedness, imaginative understanding, and location within historically evolving traditions (Johnson 1987: 175).

Closely related to non-objectivist semantics is the embodied andenactive approach to cognition. One of their proponents is Varela, who quotes Husserl:

to understand cognition one cannot take the world naively (naive realism), but we must see it instead as having the mark of our own structure, and this structure is something that one is cognizing with his own mind. (Varela, Thompson, and Rosch 1991:16)

Knowledge, thus defined, is the result of an ongoing interpretation that emerges from our capacities of understanding (cognitive realism), that are rooted in the structures of our biological embodiment but are lived and experienced within a domain of consensual action and cultural history (1991: 15). This is, in fact, a non-objectivist orientation that views

[609] cognition as enaction and that is consonant with the experientialist approach' to cognition (Johnson 1987; Lakoff 1987). This is, in fact, a 'cognitive semantics' that accounts for what meaning is to human beings, rather than trying to replace humanly meaningful thought by reference to a metaphysical account of a reality external to human experience (Lakoff 1987: 120).

The enactive approach, is a promising area of research, since it emphasizes the growing conviction that

cognition is not the representation of a pregiven world by a pregiven mind but is rather the enactment of a world and a mind on the basis of a history of the variety of actions that a being in the world performs. (Varela, Thompson, and Rosch 1991: 9) 
It is possible, therefore, to broaden the cognitive structures from the rather limited linguistic categories to those categories that are the outcome of perceptual-motor interactions with the environment (Mazet 1991: 92), restating the hypothesis that there is a correspondence between the structure of our categories and the degree of functional interaction of individuals with their environment (Dougherty 1978). What is meant here is a broadening of the field of categorization from mere perceptual to functional categorization, integrating both perceptual attributes and classes of action (Mazet 1991: 100).

The final approach is Dewey's (1958 [1934]) description of having an experience. An experience has pattern and structure because it is not just doing and undergoing in alternation, but consists of them in relationship.

Or as Dewey himself puts it:

art, in its form, unites the very same relation of doing and undergoing, outgoing and incoming energy, that makes an experience to be an experience. ... Man whittles, carves, sings, dances, gestures, molds, draws and paints. The doing or making is artistic when the perceived result is of such a nature that its qualities as perceived have controlled the question of production. The act of producing that is directed by intent to produce something that is enjoyed in the immediate experience of perceiving has qualities that a spontaneous or uncontrolled activity does not have. The artist embodies in himself the attitude of the perceiver while he works. (1958 [1934]: 48)

And again:

Without external embodiment, an experience remains incomplete ... It is no linguistic accident that 'building', 'construction', 'work', designate both a process and its finished product. Without the meaning of the verb that of the noun remains blank. (1958 [1934]: 51)

[610] All these approaches have something in common. They stress the importance of having an experience that is rooted in being human beings that have a body and sensorimotor strategies, besides the capability of making abstraction from the time-bounded reactivity. To develop this further it is interesting to examine in depth the concept of functional cycle, as developed by Jakob von Uexküll.

\section{The functional cycle: Linking perceptual and effector world}

The concept of 'functional cycle' was introduced by Jakob von Uexküll. It is an important conceptual tool that stresses the role of the subject in his interaction with the environment, and offers an operational tool for describing sensorimotor 
integration. Behaviors, in fact, are not mere movements or tropisms, but they consist of perception (Merken) and operation (Wirken); they are not mechanically regulated, but meaningfully organized (von Uexküll 1982 [1940]: 26).

The functional cycle describes the basic structure of the interactions between the human and animal organisms and the objects of their surrounding worlds. These interactions consist principally of two acts: a neutral object from the environment is 'harpooned' as a meaning-carrier by a perceiving organ or a perceiving cell, and it is then modified by the effector organ (as meaning utilizer) in such a way that it disappears again from the surrounding-world ( $\mathrm{T}$. von Von Uexküll 1987: 170). The object and the subject are thus dovetailed into one another to constitute a systematic whole.

The relations between subject and object are best shown by the diagram of the functional cycle ${ }^{l}$ as described by von Uexküll:

Figuratively speaking, every animal grasps its object with two arms of a forceps, receptor and effector. With the one it invests the object with a receptor cue or perceptual meaning, with the other, an effector cue or operational meaning. But since all of the traits of an object are structurally interconnected, the traits given operational meaning must affect those bearing perceptual meaning through the object, and so change the object itself. (1957 [1934]: 10)

The simple functional cycle teaches that both receptor and effector cues are the subject's manifestations, and that the qualities of objects included in the functional cycle can be regarded as their bearers only. Thus we ultimately reach the conclusion that each subject lives in a world composed of mere subjective realities, and that even the Umwelten themselves represent only subjective realities (1957 [1934]: 73).

[610] This is an important aspect. Especially with regard to music, the role of the interpreter is a crucial one. But also in biology, the role of the observer is important. Biology and semiotics are thus intertwined, and it is clear that von Uexküll was not merely a biologist, but rather one of the largely forgotten fathers of semiotics.

\section{Functional cycle and sensorimotor integration}

The concept of sensorimotor integration is an important notion in biology. It oses the question as to the origin of structural solidarities and functional cohesions that are to be found in the individuation of biological systems and the 
interdependency of the organism and its environment. The individual memory, for example, is the outcome of its capacity to control its present activities in terms of personal experiences that are the outcome of previous activities. The organism enriches, in a way, its repertory of genetic adaptations in supplementing it with acquired dispositions that are immediately at hand and mobilizable when confronted with a situation that can be foreseen or recognized as a familiar one (Paillard 1994a: 925).

What is meant here, is a coupling of action and perception. Although the experimental psychology of action has been largely neglected in favor of the psychology of perception, there is now a growing body of research that focuses on action and motor imagery (Annett 1996; Berthoz 1997; Decety 1996; Deecke 1996; Jeannerod 1994; Paillard 1994a) and on the concept of perception as active exploration (Berthoz 1997). The older insights of von Uexküll and Piaget are interesting examples of theoretical claims that can be matched against modern empirical evidence.

Piaget probably had no contact with the work of Jakob von Uexküll. There is, however, a certain similarity in von Uexküll's concepts of Merkwelt - the world of sensing - and Wirkwelt - the world of acting - and Piaget's notion of the 'sensorimotor level'. Both authors were profoundly influenced by Kant's insights that whatever we call knowledge is necessarily determined to a large extent by the knower's way of perceiving and conceiving (Glasersfeld 1995b: 55). The fundamental analogy lies in the concept of circularity. von Uexküll, in fact, labeled his concept of sensorimotor integration as 'functional cycle' or 'functional circle' (Funktionskreis). Piaget introduced the concept of 'circularity' which supersedes the traditional reflex concept of the linear stimulus-reaction chain. Since every stimulus presupposes a readiness to react, this readiness 'selects' as a stimulus a phenomenon of the environment which had been neutral up to that point. As the stimulus must realize the [612] reaction, however, the reflex can only be described as a circular event, in which a neutral phenomenon receives a property which it does not have independently from the reacting organ, and which it loses again after the completion of the reflex. Circularity of stimulus and reaction has, therefore, two meanings: without the readiness to react, there can be no stimulus, and with the cessation of the readiness to react, the stimulus ceases to be a stimulus, and without a stimulus there can be no reaction (T. von Uexküll 1986a: 122-123).

Reflexive action, according to Piaget $(1937,1945,1967)$, essentially consists of three parts: a pattern of sensory signals which, from an observer's point of view, may be considered the effect of an external stimulus; an activity, triggered by the particular pattern of sensory signals and which an observer may consider a response; and, subsequent to the activity, the experience of some change which, 
sooner or later, is registered as the consequence of the activity and which turns out to be beneficial for the actor. The consequence is, in fact, the reason why particular activities are linked to particular perturbations (Glasersfeld 1995b: 153). From the organism's point of view, this is an 'action schema' that tends to be the basic principle of sensorimotor learning: perceived situation $->$ activity $->$ beneficial or expected result. Or to state it in another way: there is recognition of a certain situation, a specific activity asso- ciated with that situation, and the expectation that the activity produces a certain previously experienced result (Glasersfeld 1995b: 65). What matters therefore are not merely the actions themselves but their results.

This three-part model of the reflex is an interesting operational tool, since it transcends the purely reactive conception of reflexive behavior and its genetic fixedness. Purely reactive activities, in fact, are insuffcient for goal-oriented behavior with deliberate planning as they imply a direct coupling between the sensory input and the resulting effect based on a historyless (or almost historyless) transfer function of a particular automatism (Meystel 1998: 364). The action schema, further, is a key concept in Piaget's developmental theory, since it increases the internal organization and allows the organism to act in the face of perturbation. Or, as Meystel puts it:
Defining 'schema' as what is generalizable in a given action, he believed that the memorized image furnished 'the schema of action' ... and that learning of images led to 'adaptation' of these schemata. ... This association of 'image' with 'action' in a unity of 'schema' was a powerful extension of the idea of 'percept' which contained only the first part of this couple. (Meystel 1998: 353)

It is tempting to apply these insights to the experience of dealing with music (see e.g., Gromko and Poorman 1998; Mikumo 1994). Schooled [613] listening, in fact, is not merely reactive but involves a kind of active processing of the sound that involves both the construction of an internal model of the sonic Umwelt and a kind of circularity that couples perception with action. Sensorimotor strategies are really important here, but they are conservative in keeping step with the real unfolding of the sonorous articulation. Real enactive listening is proactive, in this sense that the listener can make anticipations as to the evolution of the sound, and this on the basis of an internal model. This fits well the newer paradigms in neuroscience that transcend the conception of the brain as a reactive machinery that is able to respond in an automatic way to the solicitations of the environment through a coordinated mobilization of preadapted sensorimotor tools. This was the domain of reflexology that influenced profoundly modern physiology and behavioral psychology (conditioned reflexes). Crucial in this methodology is the concept of 'black box' with a restricted interest in the identifiable relations between sensory input and motor output. This reductionist approach has been relinquished by the 
introduction of intermediary hypothetical variables that refer to mental operations that are interposed between the perception of the stimulus and the triggering of the action. This was the start of the cognitive approach with as central topics the role of representation and the formation of an internal model of reality (Paillard 1994b: 926). Besides a direct reactivity to external stimulation, there is also a level of integration that requires a certain representation of previsible stabilities of the external world and a certain schema of postural states of the body and their previsible transformations during movement. 'The articulation of these representations, then, offers the organisms the possibilities of acting instead of merely reacting. It is through the possibilities of anticipation and extrapolation that the organism is capable of elaborating action projects and their effective realization in acts' (Paillard 1994b: 926; see also Berthoz 1997: 7). The analogies with von Uexküll's concept are obvious (Berthoz 1997: 190).

Dealing with music involves perception as well as action. This is obvious in playing music, but also in listening, there is a coupling with action, be it at an internalized level (Reybrouck 2001). Perception, in fact, involves the same neural substrates as action (the supplementary motor area) and the same holds true for imagined action (Berthoz 1996, 1997; Di Pellegrino et al. 1992; Jeannerod 1994; Annett 1996; Decety 1996). Perception, therefore, can be considered as simulated action, and the brain can be conceived as a biological simulator (Berthoz 1997). This is in a way related to Piaget's claim that knowledge arises from the subject's activity, either physical or mental, and that it is goal-directed activity that gives knowledge its organization: '.. all knowledge is tied to action.

[614] and knowing an object or an event is to use it by assimilating it to an action scheme ...' (Piaget 1967: 14-15). But the same idea was promoted by von Uexküll who said that, in order to arrive at an understanding of what the things mean, it is necessary to study their action.

\section{Functional cycle and Umwelt}

The concept of functional cycle is an important conceptual tool for every theory of knowledge. It brings together action and perception, and enables us to define the subjective worlds or Umwelten of living beings. Subjects, in fact, can be related to the same or to different objects by several functional cycles. To quote von Uexküll: 'Every action that consists of perception and operation imprints its meaning on the meaningless object and thereby makes it into a subject-related meaning-carrier in the respective Umwelt' (von Uexküll 1982 [1940]: 31). Umwelten, therefore, are not out there, but are constructed and constrained: 
The Umwelt of any animal that we wish to investigate is only a section carved out of the environment which we see spread around it - and this environment is nothing but our human world. The first task of Umwelt research is to identify each animal's perceptual cues among all the stimuli in its environment and to build up the animal's specific world with them. (von Uexküll 1957 [1934]: 13)

And further:

The Umwelt only acquires its admirable surety for animals if we include the functional tones in our contemplation of it. We may say that the number of objects which an animal can distinguish in its own world equals the number of functions it can carry out. If, along with few functions, it possesses few functional images, its world, too, will consist of few objects. As a result its world is indeed poorer, but all the more secure. ... As the number of an animal's performances grows, the number of objects that populate its Umwelt increases. It grows within the individual life span of every animal that is able to gather experiences. For each new experience entails a readjustment to new impressions. Thus new perceptual images with new functional tones are created. (von Uexküll 1957 [1934]: 49)

The same applies to music and the way the listener constructs his musical Umwelt. The qualities listeners can attribute to sounds are not reducible to the objective qualities of sound, but impinge upon a whole domain of imaginative projections that emerge from recurrent patterns of sensorimotor and ideomotor activity (Reybrouck 2001). In what follows, I will try to show that the acquisition of listening strategies is largely analogous to the construction and building of a sonic Umwelt.

\section{[615] Umwelt and music}

Raising naive listeners to the status of expert listeners is a program that is somewhat related to Piaget's genetic epistemology, as well as to von Uexküll's biological methodology and the claims of radical constructivism.

Central in Piaget's genetic epistemology is the problem of the formation and the meaning of knowledge. Or, as he formulated the problem: by what means does the human mind go from a state of less suffcient knowledge to a state of higher knowledge? (Piaget 1970: 11-12). von Uexküll's biological methodology is concerned with three basic questions: how does the animal perceive its environment? how does the animal construct its reaction in the case of learning? and what is the purpose of an animal's action? The claims of radical constructivism, finally, are built upon Piaget's theory of cognitive development and are reducible to two basic principles: knowledge is not passively received but built up by the cognizing subject, and the function of cognition is adaptive and serves the organization of the experiential world, not the discovery of onto- 
logical reality (Glasersfeld 1995b: 18). Radical constructivism is a theory of active knowing rather than a traditional theory of knowledge or epistemology. From this standpoint, as Piaget maintained fifty years ago, knowledge serves to organize experience, not to depict or represent an experiencer-independent reality (Glasersfeld 1991: xviii).

In an attempt to bring together these approaches I argue that expert listeners build up their Umwelt, and emancipate themselves from mere causal reactivity to a kind of freedom and autonomy.

A first question concerns the construction of his experiential musical world, and here I'm leaning heavily on the empirical findings of Piaget. He stated that the constructive activity during the first two years of life lays the foundations of what will become the child's experiential world: it forms the essential scaffolding for all further constructing. As the child's living experience expands, layer upon layer of conceptual constructs is built upon this foundation (Glasersfeld 1995b: 59). Listeners also must lay a foundation for further constructing, and this is essentially a matter of interaction with the sonic environment, or, as Gibson (1979) puts it: the most important kinds of perceptual learning happens when the organism interacts with its environment, that is, both perception and action are involved in the acquisition process (see also Parncutt 1994). A living organism, however, is dwelling not simply in an environment, but in an Umwelt where each object has a meaning. This world includes the body and surrounding objects which it uses in its activities. Advanced organisms, such as humans and higher animals, are capable of building new interactions with their environment and of changing existing ones.

[616] One could say, that man constructs his own Umwelt within social, cultural, and physical constraints. Each human being, as Sharov puts it, has a kind of thesaurus by which he can describe his Umwelt.

According to Hoffmeyer (1996), consciousness appears when an organism discovers that it is the builder of its own Umwelt. Because of this circular reference, humans obtained freedom to reinvent semiotic relationships with the world, which enormously speeds up the evolution of Umwelten. There is, in fact, not one Umwelt, but multiples of Umwelten, dependent upon the organism's perceptual and effector cues. Due to language, however, human beings are sharing their Umwelt to an extent which is totally beyond the possibilities of non-linguistic animals. The cognitive capability of the human species allows for a transcending of the world of immediate experience thereby eventually constituting a world of things (von Uexküll 1982 [1940]). But while we can and do transcend the world of personal experience, we do not, according to von Uexküll, have any means to transcend the species-specific Umwelt of the 
human being as such (Hoffmeyer 1998: 470). Or as Wallin puts it:

The stimulus as a releaser of a purposive behavior _ is weighed by the organism not only by means of auditory capacity in analyzing an acoustical event, but through a simultaneous evaluation of the event's significance as well. The actionoriented behavior of the organism is determined by its genetically prescribed, speciesbound program, linked to the actual space occupied by the species. The neural representation of the stimulating event therefore largely depends on the environmental pressure on the organism within this niche. Any action-oriented behavior involves modulating forces adding to the motor-sensory capacity of the organism when evaluating the external world: attention, emotion, volition, memory and learning. (1991: 231)

Building up an Umwelt is thus not fortuitous, but is rooted in our biological functioning, and is related to universals of knowing and perception (for a review of universals in music, see Miereanu and Hascher 1998; Normet 1998; Marconi 1998; Kon 1998; Padilla 1998; Brunner 1998). According to Murdock (1945) there are three categories of universals, corresponding to primary, genetically coded (instinctive) impulsions, to acquired habits, rooted in fundamental biopsychological demands, and to cultural habits with only very thin links to the conditions of the secondary level. A somewhat analogous distinction has been drawn by Bystřina (1983) who distinguishes between primary, secondary, and tertiary codes. Primary codes are of an innate nature (genetic code, perception code, and intraorganismic code), secondary codes are the result of a learning process (language code), and tertiary codes operate at the level above the secondary code (cultural codes) (see also Jiranek 1998).

[617] It is possible, however, to transcend the lower levels and to emancipate oneself from mere causal relatiornships. As Buck puts it: 'We enter the cradle as a mixture of inherited tendencies for which we are not in the least responsible, and all our reactions will be in accordance with them unless in later life we learn to modify them through training and education'. And this training and education is nothing more than 'one prolonged endeavour to substitute acquired reactions for native ones' (1961 [1944]: 12).

The same holds true for dealing with music. One can rely on a kind of direct perception, without musical conscious processing, with musical signals that trigger reactions in a quasi-automatic way. Expert listeners, however, transcend this causal reactivity in providing cognitive mediation between the acoustic signals and their reactions, and in searching richer ecological niches. To quote Edelman:

When we consider the world, there is no given semantic order: an animal must not only identify and classify things but also decide what to do in the absence of prior detailed descriptive programs handed down by evolution. This point 
deserves emphasis, because it is central to all other considerations: in some sense, the problem of perception is initially a problem of taxonomy in which the individual animal must 'classify' the things of its world. Whatever solutions to this problem are adopted by an individual organism, they must be framed within that organism's ecological niche and for its own adaptive advantage. In other words, the internal taxonomy of perception is adaptive but is not necessarily veridical in the sense that it is concordant with the descriptions of physics. (Edelman 1987: 26)

The results of our cognitive efforts have the purpose of helping us to cope in the world of our experience, rather than the traditional goal of furnishing an objective 'representation of a world as it might "exist" apart from us and our experience' (Glasersfeld 1991: xv).

\section{Introducing the observer}

In the introduction I stated that dealing with music can be considered as a theory of knowledge, hence the term epistemology of music. The listener, in fact, can be conceived as an observer who brings with him his observational tools. There is a striking parallel here with the epistemological claims of Maturana:

We are seldom aware that an observation is the realization of a series of operations that entail an observer as a system with properties that allow him or her to perform these operations, and, hence, that the properties of the observer, by specifying [618] the operations that he or she can perform determine the observer's domain of possible observations _ In other words, we are not usually aware that science is a closed cognitive domain in which all statements are, of necessity, subject dependent, valid only in the domain of interactions in which the standard observer exists and operates. (Maturana 1978: 28-29)

The critical point in this is the role of the subject and the way he constructs and organizes his knowledge. This has already been stated by Kant, but it was reformulated by von Uexküll:
All reality is subjective appearance. This had to be the great, fundamental understanding also of biology _ Kant has put the subject, man, in opposition to the objects and has discovered the fundamental principles according to which the objects are formed in our mind. The task of biology is to widen the results of Kant's research in two directions: (1) to take into account the role of our body, especially of our sense-organs and our central nervous system and (2) to explore the relations of other subjects (the animals) to the objects. (von Uexküll 1973 [1928]: 9- 10)

Living organisms (including cells) thus respond as subjects that respond to signs and not to causal impulses. This is an important point, since one of the major claims of semiotic functioning is a kind of emancipation from mere causality, 
or, as Cariani puts it, of 'the formation of ever more autonomous material organizations that gradually lift matter from inert, time-bound reactivity to ever wider realms of spatio-temporal freedom and epistemic autonomy' (1998: 243).

As I stated thus far, the objective qualities of the objects of knowledge are not suffcient ground for their perception by the listener. Music only has the possibility of oÄering dimensions that are possible carriers of form, as, for example, pitch, duration, timbre, brilliance, spatial position and dynamics (McAdams 1989; Dufourt 1989). The structural descrip tion of the objects of knowledge, therefore, has to be supplemented with a functional approach. This was stressed by Piaget (1968) who claimed the necessity of adding a subject to the structures as a 'center of functioning', but von Uexküll argued on similar lines:

Due to its integration into a functional circle, every meaning-carrier becomes a complement of the animal subject. In the process, particular properties of the meaning-carrier play a leading role as perceptual cue-carriers or effector cue-carriers; and other properties, on the other hand, play only a subsidiary role. (1982 [1940]: 33)

The functional approach thus involves selectivity and intentionality. The functional cycle, in fact, operates by means of trigger mechanisms:

[619] objects that are selected on account of their importance act as perceptual cue bearers, while other objects pass unnoticed, and objects with an operational meaning act as functional cue bearers. Both are related in the sense that the functional qualities aÄect the perceptual ones. They transform the object of perception by giving it a functional tone. Our relation to the world, therefore, is not a representational, but a functional one.

Dealing with music also relies upon a functional approach. What matters is epistemology and not the representation of ontological reality. The way a listener experiences the music thus is not reducible to the structural description of the sound. The technical marvels of sound analysis and engineering did not lead to better music understanding. What is really important is not the acoustical description of the sound, but the sounds as they are experienced by the listener. The listener's intentions are prevailing here, since music, as a temporal art, is leaning upon focusing and selecting processes by the music user. To quote Bamberger: 'The mark of the sophisticated musician is the capacity to shift focus to select for attention multiple kinds of features and relations and to coordinate them in various ways depending on "when and what for" '. This is an ontological problem: 'On the view that the sense made of phenomena is always a construction ... each of the individuals finds in the material and thereby gives existence to aspects that simply do not exist for the other' (1991: 174).

What is of primary concern is the relation between subject and object, between 
experiencing and the experienced and between knowing and the known (Tarasti 1998). Reality, and also the sonorous reality, thus is not to be found 'outside' the observer, but manifests itself in those worlds that surround all living beings like a bubble and that were described by von Uexküll as Umwelten. They are clearly delineated but are invisible to outside observers, and it is a major task of music education to delineate these respective musical Umwelten, as listeners bring with them diÄerent listening strategies and musical competences. Rather than speaking in terms of the musical Umwelt, I therefore propose to speak about respective Umwelten that are continuously changing as a result of interaction with the sonic environment, and that show different perspectives on the same musical signals. The existence of different musical Umwelten, however, does not mean that they do not have anything in common. Most animals and men, according to Cariani, have neural coding strategies that are used in representing and processing sensory information. And while the particular experiential textures of things, their qualia, undoubtedly vary among different vertebrates, the basic body-plans, sensory organs, and neural representations are roughly similar. We see in different colors, hear in different frequency registers, [620] and smell different odors, but the basic relational organizations of our percept-spaces in the end may not be so radically different (1998: 17). In this sense, much has to be expected from the biosemiotics of perception and action.

Human beings, further, are biologically adaptive systems with similar basic lifeimperatives like breathing, eating, drinking, sleeping, and mating, and higherlevel processes of cognitive functioning. Our adaptation involves interaction with the environment, and can transcend the material aspects of these environments in building up an Umwelt. There are, however, differences between higher and lower organisms. To quote von Uexküll:

The plant possesses no special Umwelt organs, but is immersed directly in its habitat. The relationships of the plant with its habitat are altogether different from those of the animals with their Umwelts. The building-plans of animals and plants are the same in only one respect. Both select precisely from among the stimuli that impinge upon them from the environment. (1982 [1940]: 33)

The principles of selection, however, are numerous. One has to distinguish here between mere time-bound reactivity and higher level cognitive processes that are the outcome of mediation between sensory input and reaction (Reybrouck 1999). Especially music, as a man-made and cultural construction, offers stimuli that transcend the wired-in reactions on standardized stimuli. Rather than claiming principles of selection on a priori grounds, as is possible in lower organisms, I propose to use two methodological tools of von Uexküll's Umweltresearch: delimitation of the meanings-carriers and participatory observation. The transformation of neutral objects into meaning-carriers that take on a 
meaning is a decisive step. The meaning is determined by the animal subject that transforms it into a sign in its sign system (T. von Uexküll 1987: 163, and for an application to music: Gobin and Delalande 1998).

The participatory observation, on the other hand, can only be under stood by precise definition of the terms. Observation means that one ascertains which of the signs that the observer registers in his external world are received by the living being under observation. This requires an exact analysis of the sensory organs (receptors) of these living beings. Once this is accomplished, it is possible to observe how the living being decodes the signs it receives in the course of its behavioral activity. Participation, on the other hand, means reconstruction of the Umwelt of another living being, or the ratification of the decoding processes in its behavior after the enumeration of the signs the living being is capable

[621] of receiving, as well as the code by means of which it interprets the signs (T. von Uexküll 1982: 4, 1987: 149).

\section{Multiresolutional Umwelten}

It is tempting to apply these intentions to the description of the subjective musical universes. Listeners, in fact, are so different in the way they cope with their acoustical environment, that the description of their meaning-carriers is a challenging research area for musical semantics. In order to do so, there is need of a domain that contains the elements to build the sounding event that can be categorized as a sign. This domain, I propose to call the sonic world or sonic universe (Reybrouck 1998b; see also Cogan 1984; Cogan and Escot 1976), and within this universe the listener can delimitate his elements and apply mental operation to these elements. These elements are signs that can be handled in a symbolic way. A major contribution to this domain has been the morphological characterization of sonorous articulation by Schaeffer (1966; see also Chion 1983; Delalande 1998) and the whole field of morphodynamical modeling of sound (Helmuth 1996).

Music knowledge, thus, is a kind of relational network of symbols (I will not enter here into the discussions between the symbolic and subsymbolic paradigm, in which I hold a hybrid position, stating that dealing with music involves both symbolic and subsymbolic processing of the sound) in which relations among the symbols and a swarm of symbols are also symbols (Meystel 1998: 348). These networks, however, can operate at different levels of granularity or resolution. A nervous system, according to Meystel, cannot deal with the whole network at a particular level of resolution. It selects a 'scope of attention' and no more knowledge is processed than that which goes into its scope of attention. It 
turns out that the nervous system is built specifically to enable us to deal with the processes of generalization and with the opposite processes of instantiations. Too much diversified information about any subject usually means that it calls forth generalization, with the creation of a new symbol. Each swarm integrates an enormous number of other symbols, and encapsulates information from these symbols into a structure of swarm which carries new information characteristic of this new creature. This construction of the infinite nestedness of swarms within swarms is primarily object-oriented and has the advantages that come with multiple granularities and nestedness. It has an enormous power of interpretation, but this at the cost of high resolution knowledge: the more generalized the knowledge is, the more details [622] seem to disappear within generalized entities (1998: 349). The concept of multiresolutional Umwelt seems likely to be an interesting conceptual tool in this context:

\begin{abstract}
'Resolution' is understood as the degree of ability to formulate details. Living creatures often waive the opportunity to formulate details in a complex situation in order to be able to manage the 'larger picture', to deal with the larger scope of attention and the alternatives that can be offered within this scope. Multi-resolutional nesting presumes the ability to synthesize strings of alternate behavior. Decomposition is typically associated with formation of parallel high resolution schemata which can be unified in a lower resolution schema. (Meystel 1998: 355)
\end{abstract}

It is tempting to apply this to the process of dealing with music. Listening, in fact, can be conceived of as a kind of scanning of the sonorous articulation, breaking the continuous image of the sound into a grid of acoustic 'pixels', somewhat analogous to the process of pixelization, sampling, scanning, or spatial quantization, as the terms are used in spatial resolution. To quote Godøy:

There may be 'high-speed' or 'broad-band' types of representations in the form of concentrated graphical overviews showing longer stretches of temporal unfolding 'at a glance', or there may be 'slower' or more 'sequential' types of 'frame by frame' overviews. For this reason, I believe that a multiplicity of temporal representations is not only possible and legitimate, but even highly desirable, as each velocity of representation can provide a diëerent kind of perspective, hence a different kind of knowledge of the musical substance. (Godøy 1997a: 66)

And further:

This question of different velocities will then also concern what I shall call resolution and perspective, both of which are perhaps rather 'atemporal' terms in ordinary usage. But once time is accepted as a morphological dimension of the musical object, the link between temporality, resolution and perspective will become a useful strategy in music theory. I think we should really have no inhibitions about using such 'visual' terms provided they are useful for our purposes. (Godøy 1997a: 66) 
There is a remarkable analogy between this concept of resolution and the way von Uexküll described his empirical findings about visual space:

Since any image can be transformed into a place-mosaic by superimposing a fine mesh or lattice on it, this method makes it possible to render the difference between the place-mosaics of various animal eyes. By diminishing a picture more and more, photographing it again with the same lattice, and then [623] re-enlarging it, we shall obtain a progressively coarser mosaic. Since the lattice photographed with the picture is disturbing, the coarser mosaic-images have been reproduced as water colors, without the lattice. Figures [1b] to [1d] were made by the lattice method. (von Uexküll 1957 [1934]: 21)

These findings are illustrated in Figure 1.

\section{Biology, epistemology, and music}

In an attempt to bring together biology, epistemology, and music, I have argued already for a biological and functional interpretation of the process of dealing with music (Reybrouck 1997). Paradigms, in fact, are changing, and there is considerable evidence now for an experiential theory of cognition that is rooted in our biological embodiment, stressing both the role of the body and the mind (Varela, Thompson, and Rosch 1991; Johnson 1987). It was Bateson (1972, 1985) who first opposed those scientists who attempted to reduce everything to mere matter, while re-introducing 'Mind' back into the scientific equations. From his point of view, mind is a constituent part of material reality, and it is nonsensical to split it from matter. Early cybernetic researchers, for instance, quickly realized that 'the science of observed systems' cannot be divorced from 'the science of observing systems' (Foerster 1974) because it is we who observe. The cybernetic approach is centrally concerned with this unavoidable limit of what we can know, i.e., our own subjectivity. Cybernetics, therefore, is aptly called 'applied epistemology', and its utility lies in the production of useful descriptions that include the observer in the description.

A similar strand of thought has been advocated by Maturana (1988b) who argues for a biological interpretation of the experiential world. A critical aspect in this approach are the circumstances under which an observer can be brought forth. Music education, then, could be conceived as a trial to raise naõÈve listeners to the level of higher cognitive functioning, equating expert listeners with schooled observers of the sonic environment. This learning process is not fortuitous, but is a process that can proceed along certain developmental lines, as suggested by developmental psychology. Rather than sketching these lines I limit myself to some biological foundations of cognition in general and of music 
cognition, leaning heavily on the genetic epistemology of Jean Piaget.

Piaget's theory of cognition $(1936,1937$; see also Glasersfeld 1978, 1982) is centered around the two fundamental principles of 'assimilation' [624]
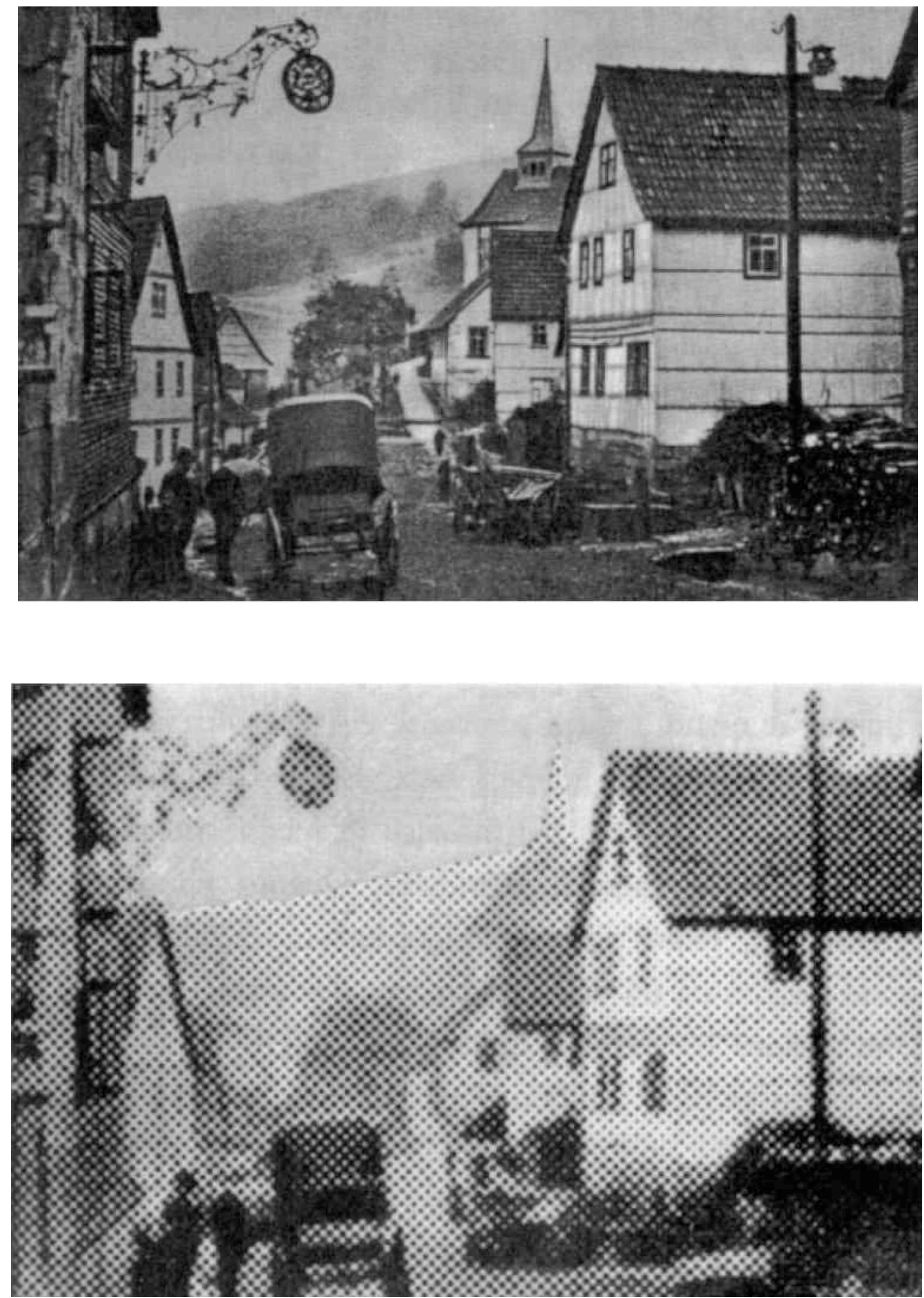

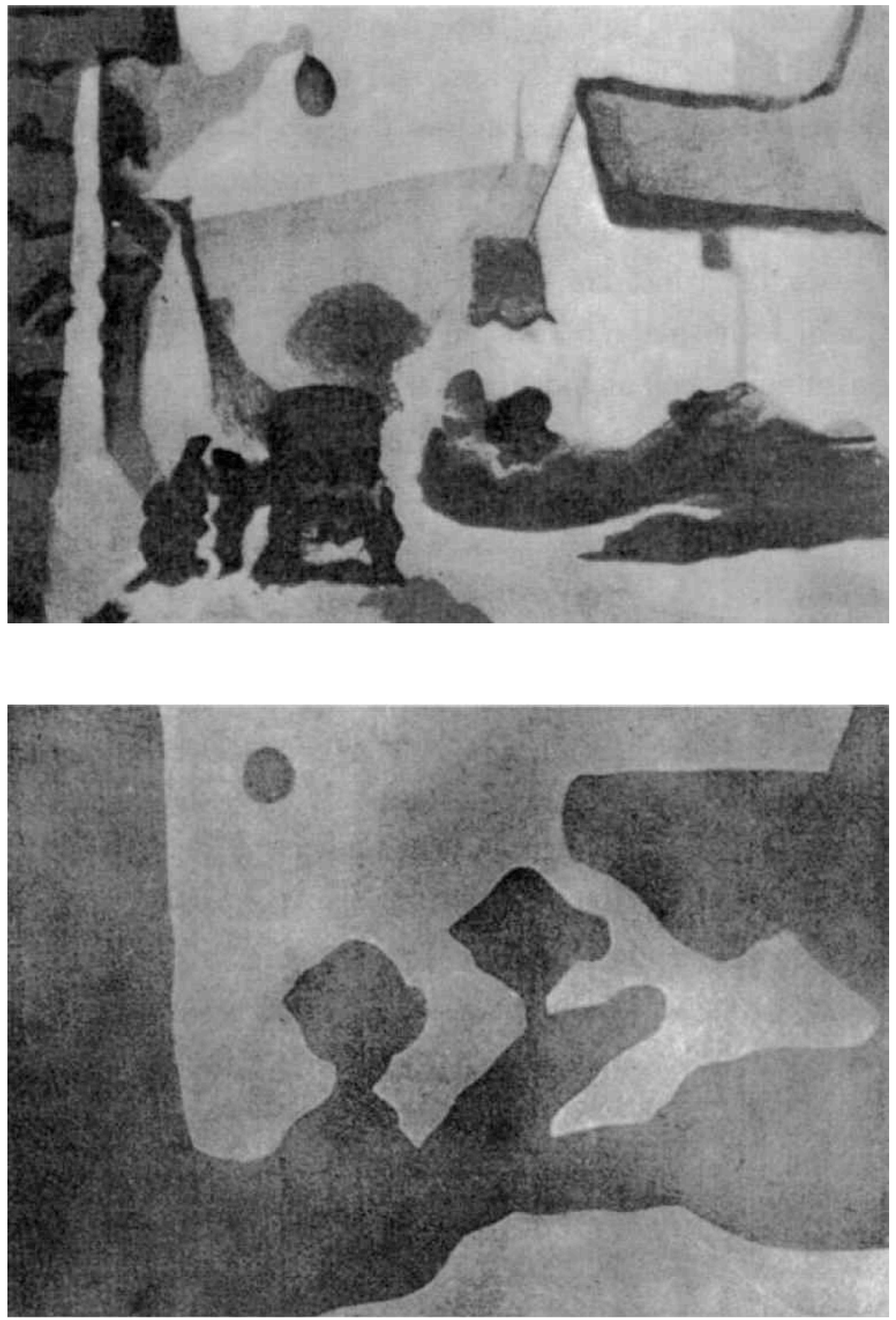
[625] Figure 1 (a-d). A village street as a photograph (a), as photographed through a screen (b), as seen by a fly (c), and as seen by a mollusc (d). After von Uexküll (1957 [1934])

[626] and 'accommodation'. The mind primarily assimilates, that is, it perceives and categorizes experience in terms of what is already known. To quote Piaget himself:

... no behaviour, even if it is new to the individual, constitutes an absolute beginning. It is always grafted onto previous schemes and therefore amounts to already constructed structures (innate, as re ${ }^{-}$exes are, or previously acquired). (Piaget 1976: 17)

Cognitive assimilation thus comes about when a cognizing organism fits an experience into a conceptual structure it already has. Only if the result of this process creates a perturbation, a review is initiated that may lead to an accommodation. That is to say, it may give rise to change in an existing structure or the formation of a new one. The principle of accommodation thus provides a mechanism for learning that is of interest to teachers of all kinds.

The concept of assimilation further illustrates the biological background of Piaget's theory of knowledge acquisition. It occupies a central position in his model of circular reactions and ensues from his sensorimotor stage in which the subject 'incorporates' its environment into itself. It allows an easy comparison with the terms Jakob von Uexküll used to describe the sign connections of biological processes, with the sensory section of his model corresponding to perception in the functional cycle and the motor section to effect (T. von Uexküll 1986a: 125).

\section{Conclusion}

In this article I have argued for an epistemology of music, stating that dealing with music can be considered as a process of knowledge acquisition. What really matters is not the representation of an ontological musical reality, but the generation of music knowledge as a tool for adaptation to the sonic world. In order to do this, I have brought together the epistemological claims of Jean Piaget, the biological methodology of Jakob von Uexküll, and the constructivistic conceptions of Ernst von Glasersfeld, stressing the role of the music user rather than the music. Dealing with music, in fact, is not a representational affair, but is a process of semiotization of the sonorous environment that is the outcome of interactions with the sound. Hence the role of enactive cognition and perceptual-motor interaction with the sonic 
environment.

What I consider to be a central issue is the way how listeners as subjects experience their own phenomenal world or Umwelt, and how they can make sense out of their sonic environment. Umwelt-research

[627] therefore is highly relevant for music education in stressing the role of the listener and his listening strategies.

\section{Note}

1. See von Uexküll's figure of the functional cycle at the beginning of this issue.

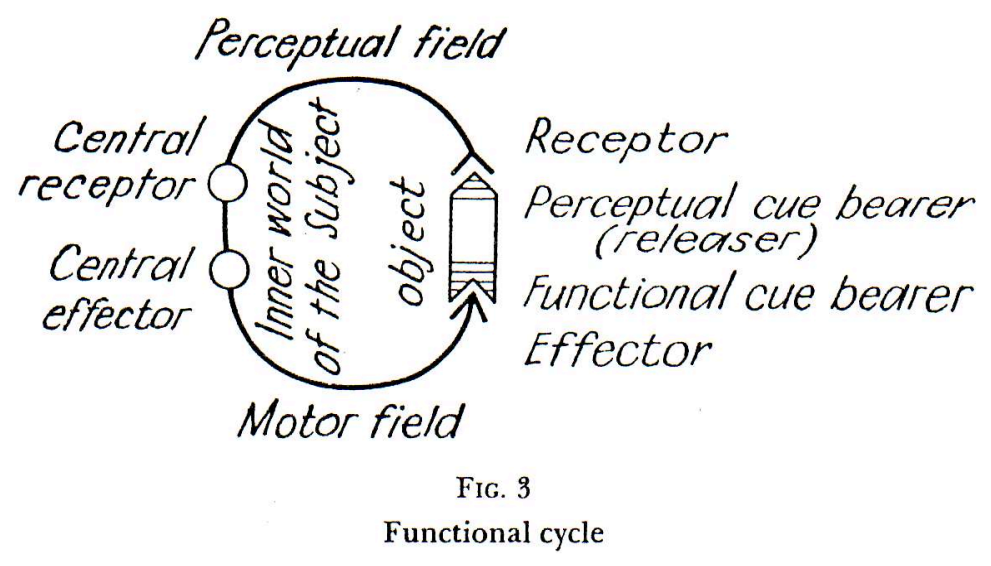

\section{References}

Aiello, Rita and Sloboda, John (1994). Musical Perceptions. New York: Oxford University Press.

Anderson, Myrdene; Deely, John; Krampen, Martin; Ransdell, Joseph; Sebeok Thomas A.; and von Uexküll, Thure von (1984). A semiotic perspective on the sciences: Steps toward a new paradigm. Semiotica 52 (1/2), 7-47.

Annett, John (1996). On knowing how to do things: A theory of motor imagery. Cognitive Brain Research 3, 65-69.

Baily, John (1985). Music structure and human movement. In Musical Structure and Cognition, Peter Howell, Ian Cross, and Robert West (eds.), 237-258. London: Harcourt Brace Jovanovich.

Bamberger, Jeanne (1991). The Mind Behind the Musical Ear. How Children Develop Musical Intelligence. Cambridge, MA: Harvard University Press. Bateson, Gregory (1985). Mind and Nature. London: Fontana Paperbacks. - (1972). Steps to an Ecology of Mind. New York: Ballantine.

Beck, Brenda (1987). Metaphors, cognition, and artificial intelligence. In 
Cognition and Symbolic Structures: The Psychology of Metaphoric

Transformation, R. Haskell (ed.), 9-30. Norwood, NJ: Ablex Publishing. Berthoz, Alain (1996). The role of inhibition in the hierarchical gating of

executed and imagined movements. Cognitive Brain Research 3, 101-113. - (1997). Le sens du mouvement. Paris: Odile Jacob.

Bystřina, Ivan (1983). Kodes und Kodewandel. Zeitschrift für Semiotik 5, 1-22.

Buck, Percy (1961 [1944]). Psychology for Musicians. London: Oxford

University Press.

Brunner, Raphaël (1998). Univers de genèse, univers de réception. In Miereanu and Hascher 1998: 637-648.

Cariani, Peter (1998). Life's journey through the semiosphere. Semiotica 120 (3/4), 243-257.

Chion, Michel (1983). Guide des objets sonores. Pierre Schaeffer et la Recherche Musicale. Paris: Buchet/Chastel.

Cogan, Robert (1984). New Images of Musical Sound. Cambridge, MA: Harvard University Press.

Cogan, Robert and Pozzi, Escott (1976). Sonic Design: The Nature of Sound and Music. Englewood Cliffs, NJ: Prentice-Hall.

Costall, Allen (1991). Phenomenal causality. In Michotte's Experimental Phenomenology of Perception, G. Thinès, A. Costall, and G. Butterworth (eds.), 51-64. Hillsdale, NJ: Lawrence Erlbaum.

Davidson, Lyle and Scripp, Lawrence (1988). Young children's musical representations: Windows on music cognition. In Generative Processes in Music. The Psychology of Performance, Improvisation, and Composition, John Sloboda (ed.), 195-230. Oxford: Clarendon Press.

DeBellis, Mark (1995). Music and Conceptualization. Cambridge: Cambridge University Press.

Decety, Jean (1996). Do imagined actions share the same neural substrate? Cognitive Brain Research 3, 87-93.

Deecke, Lüder (1996). Planning, preparation, execution, and imagery of volitional action. Cognitive Brain Research 3, 59-64.

Delalande, François (1984). La musique est un jeu d'enfant. Paris: Buchet/Chastel.

- (1987). L'analyse des conduites musicales: Une étappe du programme sémiologique? Semiotica 66 (1/3), 99-107.

- (1998). Music analysis and reception behaviours: Sommeil by Pierre Henry. Journal of New Music Research 27 (1/2), 13-66.

Deliège, Irène and Sloboda, John (eds.) (1996). Musical Beginnings: Origins and Development of Musical Competence. Oxford: Oxford University Press.

Dewey, John (1958 [1934]). Art as Experience. New York: Capricorn Books.

Di Pellegrino, G.; Fadiga, L.; Fogassi, L.; Gallese, V.; and Rizzolatti, G. (1992). Understanding motor events. Experimental Brain Research 91, 176-180. 
Dougherty, J. (1978). Salience and relativity in classification. American Ethnologist 5, 66-80.

Dowling, W. Jay and Harwood, Dane L. (1986). Music Cognition. Orlando, FL: Academic Press.

Dubois, D. (1986). La Compréhension de Phrases: Représentations

Sémantiques et Processus. Unpublished dissertation. Université de Paris VIII.

Dufourt, Hugues (1989). Musique et psychologie cognitive: Les éléments porteurs de forme. In McAdams and Deliège 1989: 327-334.

Eco, Umberto; Santambrogio, Marco; and Violi, Patrizia (eds.) (1988). Meaning and Mental Representations. Bloomington: Indiana University Press.

Edelman, Gerald (1987). Neural Darwinism: The Theory of Group Selection. New York: Basic Books.

-(1989). The Remembered Present: A Biological Theory of Consciousness.

New York: Basic Books.

Emmeche, Claus (1992). Modeling life: A note on the semiotics of emergence and computation in artificial and natural living systems. In Biosemiotics.

The Semiotic Web 1991, T. A. Sebeok and J. Umiker-Sebeok (eds.), 77-99. Berlin: Mouton de Gruyter.

Engels, Friedrich (1940). Dialectics of Nature. New York: International Publishers.

Ey, Henry (1968). La conscience. Paris: Presses Universitaires de France.

- (1984). Conscience. In Encyclopedia Universalis, Corpus 5, 366-372. Paris:

Encyclopedia Universalis Paris.

Foerster, Heinz von (ed.) (1974). Cybernetics of Cybernetics. Urbana:

University of Illinois.

- (1995). Das Konstruieren einer Wirklichkeit. In Watzlawick 1995: 39-60.

Gibson, James (1966). The Senses Considered as Perceptual Systems. London: Allen \& Unwin.

-(1979). The Ecological Approach to Visual Perception. Boston: Houghton Mifflin.

-(1982). Reasons for Realism: Selected Essays of James J. Gibson, ed. by E. Reed and R. Jones. Hillsdale, NJ: Lawrence Erlbaum.

Glasersfeld, Ernst von (1978). Radical constructivism and Piaget's concept of knowledge. In The Impact of Piagetian Theory, F. Murray (ed.), 109-122. Baltimore, MD: University Park Press.

-(1982). An interpretation of Piaget's constructivism. Revue Internationale de la Philosophie 36 (4), 612-635.

-(1987). The Construction of Knowledge: Contributions to Conceptual Semantics. Seaside, CA: Intersystems Publications.

-(ed.) (1991). Radical Constructivism in Mathematics Education. Dordrecht: Kluwer Academic Press.

—(1995a). Einführung in die radikalen Konstruktivismus. In Watzlawick 1995: 
16-38.

-(1995b). Radical Constructivism: A Way of Knowing and Learning. London:

Falmer Press.

- (1996). Cybernetics and the Art of Living, Plenary address. 13th European

Meeting on Cybernetics and Systems Research, Vienna, April 9-12, 1996.

Gobin, Pascal and Delalande, François (1998). Les unités sémiotiques temporelles. Un niveau d'analyse de l'organisation musicale du temps. In Miereanu and Hascher 1998: 573-587.

Godøy, Rolf Inge (1997a). Formalization and Epistemology. Oslo: Scandinavian University Press.

- (1997b). Knowledge in music theory by shapes of musical objects and soundproducing actions. In Leman 1997: 89-102.

-(1999). Cross-modality and conceptual shapes and spaces in music theory. In Zannos 1999: 85 \pm 98 .

Godøy, Rolf Inge and Jørgensen, Harald (2001). Elements of Musical Imagery. Lisse: Swets and Zeitlinger.

Gromko, Joyce and Poorman, Allison (1998). Does perceptual-motor performance enhance perception of patterned art music? Musicae Scientiae $2(2), 157-170$.

Gruber, H. and Vonèche, J. (eds.) (1977). The Essential Piaget. London:

Routledge and Kegan Paul.

Haeckel, Ernst (1988 [1866]). Generelle Morphologie des Organismus, Bd. 2: Allgemeine Entwicklungsgeschichte. Berlin: de Gruyter.

Handel, Stephen (1989). Listening. An Introduction to the Perception of Auditory Events. Cambridge, MA: MIT Press.

Hargreaves, David (1986). The Developmental Psychology of Music. Cambridge: Cambridge University Press.

-(1996). The development of artistic and musical competence. In Deliège and Sloboda 1996: 145-170.

Haskell, Robert (1987). Cognition and Symbolic Structures: The Psychology of Metaphoric Transformation. Norwood, NJ: Ablex Publishing.

Helmuth, Mara (1996). Multidimensional representation of electroacoustic music. Journal of New Music Research 25, 77-103.

Hoffmeyer, Jesper (1996). Signs of Meaning in the Universe. Bloomington: Indiana University Press.

- (1997). Biosemiotics: Towards a new synthesis in biology. European Journal for Semiotic Studies 9 (2), 355-376.

-(1998). Semiosis and biohistory: A reply. Semiotica 120 (3/4), 455-482.

Howell, Peter; Cross, Ian; and West, Robert (eds.) (1985). Musical Structure and Cognition. London: Harcourt Brace Jovanovich.

Imberty, Michel (1996). Linguistic and musical development in preschool and school-age children. In Deliège and Sloboda 1996: 191-213.

Ingold, Tim (1992). Culture and the perception of the environment. In Bush 
Base: Forest Farm, E. Croll and D. Partin (eds.), 39-56. London:

Routledge

-(1995). Building, dwelling, living: How animals and people make themselves

at home in the world. In Shifting Contexts: Transformations in

Anthropological Knowledge, M. Stratton (ed.), 57-80. London: Routledge. Jackendoff, Ray (1987). Consciousness and the Computational Mind.

Cambridge, MA: MIT Press.

- (1988). Conceptual semantics. In Eco, Santambrogio, and Violi 1988: 81-97.

James, William (1950 [1890]). The Principles of Psychology. New York: Dover.

-(1968). The Writings of William James. A Comprehensive Edition, ed. by J.

McDermott. New York: Random House.

-(1976). Essays in Radical Empiricism. Cambridge, MA: Harvard University

Press.

Jeannerod, Marc (1994). The representing brain: Neural correlates of motor intention and imagery. Behavioural Brain Sciences 17, 187-202.

Jiranek, Jaroslav (1998). Reflexions sur les constances de sémantique musicale.

In Miereanu and Hascher 1998: 60-65.

Johnson, Mark (1987). The Body in the Mind: The Bodily Basis of Meaning, Imagination, and Reason. Chicago: University of Chicago Press.

Jones, Marie Riess and Holleran, Susan (1992). Cognitive Bases of Musical

Communication: An Overview. Washington: American Psychological

Association.

Kon, Joseph (1998). Einige Bemerkungen Über das Problem der musikalischen Universalien. In Miereanu and Hascher 1998: 197-205.

Kull, Kalevi (1993). Semiotic paradigm in theoretical biology. In Lectures in Theoretical Biology: The Second Stage, K. Kull and T. Tiivel (eds.), 52-62. Tallinn: Estonian Academy of Sciences.

-(1998a). Baerian biology: Evolution by means of organisms' interpretation. In Emergence, Complexity, Hierarchy, Organization (=Acta Polytechnica Scandinavica 91), George L. Farré and Tarkko Oksala (eds.), 197-200. Espoo: The Finnish Academy of Technology.

- (1998b). On semiosis, Umwelt, and semiosphere. Semiotica 120 (3/4), 299310.

-(1998c). Semiotic ecology: Different natures in the semiosphere. Sign Systems Studies 26, 344-371.

Lakoff, George (1987). Women, Fire, and Dangerous Things: What Categories Reveal About the Mind. Chicago: University of Chicago Press.

-(1988). Cognitive semantics. In Eco, Santambrogio, and Violi 1988: 119-154.

Langacker, Ronald (1987). Foundations of Cognitive Grammar, vol. 1. Stanford, CA: Stanford University Press.

Laske, Otto (1977). Music, Memory and Thought: Explorations in Cognitive Musicology. Pittsburgh, PA: University Microfilms International.

Leman, Marc (ed.) (1997). Music, Gestalt and Computing: Studies in Cognitive 
and Systematic Musicology. Berlin: Springer Verlag.

Lewontin, Richard (1982). Organism and environment. In Learning,

Development and Culture, H. C. Plotkin (ed.), 151-172. Chichester: Wiley. Lidov, David (1987). Mind and body in music. Semiotica 66 (1/3), 69-97.

Lorenz, Konrad (1971). Studies in Animal and Human Behaviour, vol. 2.

Cambridge, MA: Harvard University Press.

Marconi, Luca (1998). Universals in music and musical experiences. In

Miereanu and Hascher 1998: 657-666.

Martindale, Colin and Moore, Kathleen (1989). Relationship of musical

preference to collative, ecological, and psychophysical variables. Music

Perception 6 (4), 431-446.

Maturana, Humberto (1970). Biology of Cognition. Urbana: University of Illinois.

-(1978). Biology of language: The epistemology of reality. In Psychology and Biology of Language and Thought, G. Miller and E. Lenneberg (eds.), 2746. New York: Academic Press.

-(1988a). Ontology of Observing: The Biological Foundations of Self

Consciousness and the Physical Domain of Existence (=Texts in

Cybernetic Theory). Washington: American Society for Cybernetics.

- (1988b). Reality: The search for objectivity or the quest for a compelling argument. The Irish Journal of Psychology 9 (1).

Maturana, Humberto and Varela, F. (1987). The Tree of Knowledge: The Biological Roots of Human Understanding. Boston: New Science Library.

Mazet, Corinne (1991). Fonctionnalité dans l'organiation catégorielle. In Sémantique et cognition: Catégories, prototypes, typicalité, D. Dubois (ed.), 89-100. Paris: Editions du CNRS.

McAdams, Stephen (1989). Contraintes psychologiques sur les dimensions porteuses de forme en musique. In McAdams and Deliège 1989: 257-280.

- (1993). Recognition of sound sources and events. In McAdams and Bigand 1993: 146-198.

McAdams, Stephen and Bigand, Emmanuel (1993). Thinking in Sound: The Cognitive Psychology of Human Audition. Oxford: Clarendon Press.

McAdams, Stephen and Deliège, Irène (eds.) (1989). La musique et les sciences cognitives. Liège: Pierre Mardaga.

McDermott, John (1968). The Writings of William James. A Comprehensive Edition. New York: Random House.

Merleau-Ponty, Maurice (1942). La structure du comportement. Paris: Presses Universitaires de France.

Merrell, Floyd (1998). Does the life of signs yield a meaningful universe? Semiotica 120 (3/4), 311-342.

Meystel, Alex (1998). Multiresolutional Umwelt: Towards a semiotics of neurocontrol. Semiotica 120 (3/4), 343-380.

Miereanu, Costin and Hascher, Xavier (eds.) (1998). Les Universaux en 
musique, Actes du 4e Congrès international sur la signification musicale. Paris: Publications de la Sorbonne.

Mikumo, Mariko (1994). Motor encoding strategy for pitches of melodies. Music Perception 12 (2), 175-197.

Molino, Jean (1988). La musique et le geste: Prolégomènes à une anthropologie de la musique. Analyse musicale 10, 8-15.

Murdock, George (1945). The common denominator of cultures. In The Science of Man in the World Crisis, R. Linton (ed.), 123-142. New York: Columbia University Press.

Neisser, U. (ed.) (1987). Concepts and Conceptual Development: Ecological and Intellectual Factors in Categorization. Cambridge: Cambridge University Press.

Normet, Leo (1998). Universals and their subdivisions. In Miereanu and Hascher 1998: 191-195.

Nöth, Winfried (1998). Ecosemiotics. Sign Systems Studies 26, 332-343.

Padilla, Alfonso (1998). Les universaux en musique et la définition de la musique. In Miereanu and Hascher 1998: 219-230.

Paillard, Jacques (1977). La machine organisée et la machine organisante. Revue de l'Education Physique Belge 27, 19-48.

-(1990). Réactif et Prédictif: Deux modes de gestion de la motricité. In

Pratiques sportives et modélisation du geste, V. Nougier and J-P. Bianqui (eds.), 13-56. Grenoble: Université Joseph-Fourier.

- (1994a). La conscience. In Traité de psychologie expérimentale, vol. 2, M.

Richelle, J. Requin, and M. Robert (eds.), 639-684. Paris: Presses Universitaires de France.

-(1994b). L'intégration sensori-motrice et idéo-motrice. In Traité de psychologie expérimentale, vol. 1, M. Richelle, J. Requin, and M. Robert (eds.), 925-961. Paris: Presses Universitaires de France.

Papoušek, Hanuš (1996). Musicality in infancy research: Biological and cultural origins of early musicality. In Deliège and Sloboda 1996: 37-55.

Parncutt, Richard (1994). Template-matching models of musical pitch and rhythm perception. Journal of New Music Research 23, 145-167.

Piaget, Jean (1936). La naissance de l'intelligence chez l'enfant. Geneva: Delachaux et Niestlé .

-(1937). La construction du réel chez l'enfant. Geneva: Delachaux et Niestlé .

- (1945). La formation du symbole chez l'enfant. Neuchâtel: Delachaux et Niestlé .

-(1967). Biologie et connaissance. Essai sur les relations entre les régulations organiques et les processus cognitifs. Paris: Gallimard.

- (1968). Le structuralisme. Paris: Presses Universitaires de France.

- (1970). Genetic Epistemology. New York: Columbia University Press.

- (1974). La prise de conscience. Paris: Presses Universitaires de France.

- (1976). Piaget's theory. In Piaget and His School, B. Inhelder and H. 
Chipman (eds.), 17. New York: Springer

- (1977). Foreword. In Gruber and Vonche 1977: xi.

Pobojewska, Aldona (1993). Die Umweltkonzeption Jakob von Uexkülls: Eine neue Idee des Untersuchungsgegenstandes von der Wissenschaft. In Neue Realitäten: Herausforderung der Philosophie (16. Deutscher Kongress fuÈr Philosophie, Sektionsbeiträge I), H. Lenk and H. Poser (eds.), 94-101. Berlin: Technische Universität Berlin.

Polednak, Ivan (1985). Zum Problem der Apperzeption der Musik. International Review of the Aesthetics and Sociology of Music 16 (1), 43-56.

Pylyshyn, Zenon (1985). Computation and Cognition: Toward a Foundation for Cognitive Science. Cambridge, MA: MIT Press.

Reybrouck, Mark (1989). Music and the higher functions of the brain. Interface: Journal of New Music Research 18 (1/2), 73-88.

-(1997). Gestalt concepts and music: Limitations and possibilities. In Leman 1997: 57-69.

- (1998a). Deixis, pointing and categorization as operational tools for musical semantics. Lecture delivered at the Sixth International Conference on Musical Signification, Aix-en-Provence, December 1-5.

-(1998b). Musical space. Mathematical bases and psychological constraints. Musical Praxis 5 (1), 61-77.

-(1999). The musical sign between sound and meaning. In Zannos 1999: 3958.

-(2001). Musical imagery between sensory processing and ideomotor simulation. In Godøy and Jørgensen 2001: 71-90.

Rosenthal, David (1989). A model of the process of listening to simple rhythms. Music Perception 6 (3), 315-328.

Russolo, Luigi (1975). L'art des bruits. Lausanne: Editions l'Age d'Homme. Schaeffer, Pierre (1966). Traité des objets musicaux. Paris: Editions du Seuil. Searle, John (1983). Intentionality. Cambridge: Cambridge University Press.

Sebeok, Thomas A. (1977). How Animals Communicate. Bloomington: Indiana University Press.

- (1998). The Estonian connection. Sign Systems Studies 26, 20-41.

Serafine, Marie Louise (1988). Music as Cognition: The Development of Thought in Sound. New York: Columbia University Press.

Sharov, Alexei (1991). Biosemiotics: Functional-evolutionary approach to the analysis of the sense of information. In Biosemiotics. The Semiotic Web 1991, T. A. Sebeok and J. Umiker-Sebeok (eds.), 345-373. Berlin: Mouton de Gruyter.

-(1998). From cybernetics to semiotics in biology. Semiotica 120 (3/4), 404419.

Sherrington, Charles (1940). Man on His Nature. Cambridge: Cambridge University Press.

Sloboda, John (1985). The Musical Mind: The Cognitive Psychology of Music. 
Oxford: Clarendon Press.

Stefani, Gino; Marconi, Luca; and Tarasti, Eero (eds.) (1998). Musical Signification, between Rhetoric and Pragmatics. Proceedings of the 5th International Congress on Musical Signification. Bologna: Editrice CLUEB.

Sutrop, Urmas and Kull, Kalevi (1985). Theoretical Biology in Estonia. Tallinn: Valgus.

Tarasti, Eero (1986). Music models through ages: A semiotic interpretation.

International Review of the Aesthetics and Sociology of Music 17 (1), 3-28.

-(ed.) (1987). Semiotics of Music. Semiotica 66 (1/3). [Special issue.]

- (1994). The great synthesis of Leonard B. Meyer. Semiotica 101 (1/2), 125 137.

- (1995). A Theory of Musical Semiotics. Bloomington: Indiana University Press.

- (1998). The Enchanted Signs. Bloomington: Indiana University Press.

Tighe, Thomas J. and Dowling, W. Jay (eds.) (1993). Psychology and Music:

The Understanding of Melody and Rhythm. Hillsdale, NJ: Lawrence Erlbaum.

Torop, Peeter (1998). Semiotics in Tartu. Sign Systems Studies 26, 9-19.

Trehub, Sandra and Trainor, Laurel (1993). Listening strategies in infancy: The roots of music and language development. In McAdams and Bigand 1993: $278 \pm 327$.

Von Uexküll, Jakob von (1935). Der Kampf um den Himmel. Die neue Rundschau 46, 367-379.

- (1937). Die neue Umweltlehre: Ein Bindeglied zwischen Natur- und Kulturwissenschaften. Die Erziehung 13 (5), 185-199.

-(1957 [1934]). A stroll through the worlds of animals and men. In Instinctive Behavior: The Development of a Modern Concept, Claire H. Schiller (ed. and trans.), 5-80. New York: International Universities Press.

-(1973 [1928]). Theoretische Biologie. Frankfurt: Suhrkamp.

- (1982 [1940]). The theory of meaning. Semiotica 42 (1), 25-82.

Von Uexküll, Thure von (1982). Introduction: Meaning and science in Jakob von Uexküll's concept of biology. Semiotica 42 (1), 1-24.

-(1986a). From index to icon: A semiotic attempt at interpreting Piaget's developmental theory. In Iconicity: Essays on the Nature of Culture, P. Bouissac, M. Herzfeld, and R. Posner (eds.), 119-140. Tübingen:

Stauffenburg Verlag.

- (1986b). Medicine and semiotics. Semiotica 61 (3/4), 201-217.

- (1987). The sign theory of Jakob von Uexküll. In Classics of Semiotics, M.

Krampen, K. Oehler, R. Posner, T. A. Sebeok, and T. von Uexküll (eds.), 147-178. New York: Plenum Press.

Varela, Francesco (1979). Principles of Biological Autonomy. New York: North Holland. 
Varela, Francesco; Thompson, Evan; and Rosch, Eleanor (1991). The Embodied Mind: Cognitive Science and Human Experience. Cambridge, MA: MIT Press.

Vygotsky, Lev (1962). Thought and Language. Cambridge, MA: MIT Press. - (1978). Mind in Society. The Development of Higher Psychological Processes. Cambridge, MA: Harvard University Press.

Wallin, Nils (1991). Biomusicology: Neurophysiological and Evolutionary Perspectives on the Origins and Purposes of Music. New York: Pendragon Press.

Watzlawick, Paul (ed.) (1995). Die erfundene Wirklichkeit: Wie wissen wir, was wir zu wissen glauben. München: Piper. Zannos, Ioannis (ed.) (1999). Music and Signs. Bratislava: ASCO Art \& Science.

Mark Reybrouck (b. 1952) is Professor of Music at the Catholic University of Leuven, Belgium, mark.reybrouck@arts.kuleuven.be. His research interests include musical semiotics and semantics, musical epistemology, categorization, and sensorimotor integration. 